\title{
THE TRANSLATION ACCEPTABILITY OF COMPLAIN RESPONDING TURN IN SHOPAHOLIC TO THE RESCUE
}

\author{
Setia Adi Nugraha \\ Linguistics Study Program, Postgraduate, Sebelas Maret University, Indonesia \\ Email: nugraha.setia.adi@gmail.com \\ Mangatur Nababan \\ Linguistics Study Program, Postgraduate, Sebelas Maret University, Indonesia \\ Email: amantaradja@yahoo.com \\ Djatmika \\ Linguistics Study Program, Postgradutae, Sebelas Maret University, Indonesia \\ Email:djatmika@uns.ac.id
}

\begin{abstract}
APA Citation: Nugraha, S. A., Nababan, M., \& Djatmika, D. (2019). The translation acceptability of complain responding turn in shopaholic to the rescue. Indonesian EFL Journal, 5(2), 143-150. doi: 10.25134/ieflj.v5i2.1733.
\end{abstract}

Received: 20-03-2019

Accepted: 27-05-2019

Published: 01-07-2019

\begin{abstract}
The purpose of this research was to know the translations techniques, the accuracy as well as the acceptability of the translations. It was a descriptive-qualitative research with an embedded case study by using pragmatics approach. This research was done by listing the conversations between characters in the Shopaholic to the Rescue novel which contains turns that respond to complaining speech act. Here, the source language and target language were compared to identify the translation techniques. Then, the researcher and the raters assessed the acceptability of the translations by conducting Focus Group Discussion (FGD). The result showed that there are 14 techniques used by the translator, such as established equivalent, variation, pure borrowing, modulation, explicitation, implicitation, addition, transposition, reduction, linguistic compression, literal, generalization, discursive creation, and linguistic amplification. Moreover, the average rate of the acceptability is 2.94 out of 3 which means it is prevalent, in line with the norm as well as the rule of the target language.

Keywords: acceptability; complain responding turn; translation techniques.
\end{abstract}

\section{INTRODUCTION}

Novel, as one of literature works, usually has cultural values which the writer or the author intends to deliver to the readers. Through its words and language(s), the author tries to communicate and bring the culture alive in the reader's mind. The novel itself does not only come from the locals, but also from foreign countries. It means that the language as well as the culture are completely different. Translating the words or terms related to the culture especially in literary works such as novel will be more difficult since novel, especially foreign novel, has cultural differences. Hence, in order to make the target readers understand the meaning of the source text, good translation is needed. Larsson (1998) said that translation is a changing and the changing itself happens in its language. According to Nababan (1997), one of translator's jobs is finding the equivalent words from the source text to the target text.

Novel has several items which are interesting to be selected as research items, such as communication and interaction in the novel. Communication and interaction between the characters in the novel do not only consist of words, phrases, or sentences, but also consists of culture, norms, and grammar. Nababan (2003) stated that although it is just a word, but it may have social or cultural meaning in a particular society.

Speech act as a part of pragmatics is interesting to be studied. According to Yule 
(1996), speech act is an action performed through utterances. Since speech act does not only have interactive values, but speech act also has cultural, norms, and grammatical structure. Moreover, there are a lot of speech acts in pragmatics in which one of them is complaining speech act. This research tries to relate between the turn of complaining speech act and translations. Turn, as mentioned by Sacks (in Mey, 2001), is the basic unit in conversation as well as a shift of direction in speaking.

There are some previous studies conducted in this field. Nuraeni (2008), for example, tried to compare between the translations of complaining speech act of Bad Boys II movie in the VCD version and its translation in the television version. Nuraeni's research is different from this research since Nuraeni (2008) focused on comparing the translations, while this study tries to know the translations quality of the turn(s) responding to the complaining speech act. Another related study is written by Mahesti (2016) that tried to analyze the types of complaining strategies and its translations technique. Her research is different from this research because although she used a novel as the source of data and also translations as the scope of the study, but she did not focus on the turn and only concern in the complaining strategies. Further, Nurhasanah (2010) focused on the analysis of complaining speech act in Japanese, not in English.

Although those research were talking about complaining speech act, but they do not focus on the translation of the responding turn of complaining speech act, its translation techniques used by the translator, and also the quality of the translation. This research uses pragmatics especially speech act theory in order to help to limit the data. Moreover, this research also uses translation techniques proposed by Molina and Albir (2002) and translation quality assessment instrument by Nababan, Nuraeni, and Sumardiono (2012) which consists of three aspects, namely accuracy, acceptability, and readability. Yet, this research only focuses on the acceptability since this research wants to find out whether the translation is accepted or not by the target reader. Here, acceptability belongs to the norm, culture, and rule of target language.

\section{METHOD}

This research is categorized as descriptivequalitative research with embedded case study. It is categorized as descriptivequalitative since this research is not only collecting the data, but also interpreting the data (Surrakhmand in Abdurrahman \& Soejono, 1992). Besides, this research also uses table to interpret the data (Santosa, 2014). This research focuses on analyzing the use of translation techniques in translating the responding turns of complaining speech act in the Shopaholic to the Rescue as well as the quality of the translation, namely the acceptability. Since this research focuses on the translation techniques and related to the translation of the target language, this research is called as translation research which is focused on the product (Nababan, 2007). As mentioned before, the purpose of this research is to find out the translation techniques as well as the translation quality of the responding turn of complaining speech act from the Shopaholic to the Rescue novel.

There are two data in this research, namely primary and secondary data. The primary data consists of responding turn of complaining speech acts in the Shopaholic to the Rescue in terms of words, phrases, or sentences. Meanwhile, the secondary data are the previous related research. Yet, the secondary data are not included and directly used in this research because the secondary data are only used as the references and comparison.

Moreover, this research uses content analysis. According to Yin (in Sutopo, 2006), content analysis technique is a technique used by the researcher in order to get various information in completing the research. The data, in the form of words, phrases or sentences are collected and listed. Then, it is used to identify the translation techniques. The techniques can be identified by 
comparing the source text and the target text. In order to know the translation quality, this study uses Focus Group Discussion (FGD) as a method to collect the data and also give discussion facility between the raters and the researcher. The raters involved in the FGD have Master degree in the translation and also expert in assessing translation qualities. During FGD, the raters and the researcher give the score on the translation according to the acceptability assessment instrument proposed by Nababan, Nuraeni, and Sumardiono (2012). The assessment instrument has three levels of qualitative parameter. It is from 1 to 3 . If the score is one, it means that the translation is not acceptable. If it is two, the translation feels natural, but few grammatical problems are detected. Then, if the score is three, it means that the translation is acceptable and accepted in the target language. After that, the raters and the researcher try to identify the translation techniques, calculate the scores, and find the average score of the assessment. Finally, the researchers try to find the relation between the identified translation techniques and the impact of the techniques to the acceptability of the translation.
p-ISSN 2252-7427, e-ISSN 2541-3635

https://journal.uniku.ac.id/index.php/IEFLJ/index

\section{RESULTS AND DISCUSSION}

Following the translation theory proposed by Molina and Albir (2002), it was found that there are 14 translation techniques used by the translator in translating the responding turns. They are established equivalent, variation, pure borrowing, modulation, explicitation, implicitation, addition, transposition, reduction, compensation, literal, discursive creation, generalization, and amplification. Here, the raters give the score of acceptability for each translation in which the score range is one to three. The score indicates that the translation is acceptable (3), less acceptable (2), or not acceptable (1).

\section{Translation techniques used in the novel Established equivalent}

Established equivalent becomes the most dominant translation technique used in Shopaholic to the Rescue novel. This technique uses correct translation(s) in the dictionary. Thus, it is easily found in the daily life of target language reader, such as the word 'know' becomes 'tahu (verb)', 'Well' becomes 'Yah', and 'Come on,' becomes 'Ayo.' Some examples of established equivalent are presented in Table 1.

Table 1. Examples of established equivalent

\begin{tabular}{l|l}
\hline \multicolumn{1}{c}{ Source Text } & \multicolumn{1}{c}{ Target Text } \\
\hline 'I know,' I say humbly. 'I'm sorry.' & 'Aku tahu,' kataku merendah. 'Maaf.' \\
'Well, I don't know,' I say confused. & 'Yah, aku tidak tahu, 'kataku bingung. \\
'Come on, Minnie,' I say, trying to sound light- & 'Ayo Minnie, ' kataku, berusaha terdengar ceria. \\
hearted. & \\
\hline
\end{tabular}

\section{Variation}

Variation, is the second most dominant technique found in in Shopaholic to the Rescue novel. The use of variation technique gives an impact on the translation result because variation itself is a technique of changing the linguistics element(s) which affect(s) the linguistics varieties. On the examples presented in Table 2, the translator changes the meaning of the word 'You' becomes ' $k a u$ ' and 'I' becomes ' $-k u$ '.

Table 2. Examples of variation

\begin{tabular}{l|l}
\hline \multicolumn{1}{c|}{ Source Text } & \multicolumn{1}{c}{ Target Text } \\
\hline 'But you didn't even tell Mum what you were & $\begin{array}{l}\text { 'Tapi kau bahkan tidak memberitahu Mum apa } \\
\text { doing! You just disappeared!' }\end{array}$ \\
$\begin{array}{l}\text { yang sedang kaulakukan! Kau menghilang begitu } \\
\text { saja!' }\end{array}$ & $\begin{array}{l}\text { 'Menurutku Dad tidak sedang menghabiskan } \\
\text { 'I don't think Dad's running through the familyayan keluarga, 'kataku berhati-hati. } \\
\text { fortune.' I say warily. }\end{array}$ \\
$\begin{array}{l}\text { 'You can't refuse refunds!' objects the denim-clad } \\
\text { woman. }\end{array}$ & $\begin{array}{l}\text { 'Kau tidak boleh menolak permintaan uang } \\
\text { kembali' protes wanita berbalut denim itu. }\end{array}$ \\
\hline
\end{tabular}




\section{Pure borrowing}

Pure borrowing is a technique used by the translator to borrow term(s) from the source text and put it into the target language. This technique is used to overcome translator's obstacle in translating name of the character, city, or expressive reaction(s). In Table 3, the translator puts the names of the characters on the novel in the target text without any changes, such as "Suze" (ST) becomes "Suze" in the target text, Becky as well as Minnie. There is no addition, no changes, or reduction found on those examples.

Table 3. Examples of pure borrowing

\begin{tabular}{|c|c|}
\hline Source Text & Target Text \\
\hline ‘Who, Suze?’ Luke gives a little wince. & 'Siapa, Suze?’' Luke meringis kecil. \\
\hline $\begin{array}{l}\text { 'Becky, this is not all your fault,' counters Luke } \\
\text { firmly. } \\
\text { 'Er... Minnie has no idea what it is,' I say } \\
\text { carefully. }\end{array}$ & $\begin{array}{l}\text { 'Becky, ini bukan seluruhnya salahmu,' timpal Luke } \\
\text { tegas. } \\
\text { 'Mm... Minnie tidak tahu itu apa,' kataku berhati- } \\
\text { hati. }\end{array}$ \\
\hline
\end{tabular}

\section{Modulation}

This technique is used by the translator in order to change the point of view, its focus, and/or the cognitive aspect lexically or in its structure. As it can be seen on the examples of modulation presented in Table 4, the translator tries to change the point of view from the source text into the target text, such as "I don't think" into "Menurutku", and then "Are you suffering" into "Membuatmu menderita ya?"

Table 4. Examples of modulation

\begin{tabular}{l|l}
\hline \multicolumn{1}{c|}{ Source Text } & \multicolumn{1}{c}{ Target Text } \\
\hline 'There was the sunbed in our garage,' points out & 'Mesin pencokelat kulit di garasi kami,, kata Janice. \\
$\begin{array}{l}\text { Janice. } \\
\text { 'I don't think Dad's running through the family } \\
\text { fortune.' I say warily. }\end{array}$ & $\begin{array}{l}\text { 'Menurutku Dad tidak sedang menghabiskan } \\
\text { 'Are youaan keluarga,' kataku berhati-hati. } \\
\text { 'Membuatmu menderita ya?' Luke menyeringai. }\end{array}$ \\
\hline
\end{tabular}

\section{Explicitation}

Explicitation is used to make clear an information from the source text which is still implicit in its context or situation. As it can be seen on the examples of modulation presented in Table 5, on the ST, there is only
"Did you eat anything?" while in the TT "Kalian sempat makan sesuatu?" means there is an addition "sempat" which is used to help the reader knows the information on the source text clearer.

Table 5. Examples of explicitation

\begin{tabular}{l|l}
\hline \multicolumn{1}{c|}{ Source Text } & \multicolumn{1}{c}{ Target Text } \\
\hline 'Did you drink any water? Did you eat anything?' & $\begin{array}{l}\text { 'Kalian minum air, tidak? Kalian sempat makan } \\
\text { sesuatu?' }\end{array}$ \\
\hline 'This is big stuff. It's hard.' & 'Ini masalah besar. Sulit.' \\
\hline
\end{tabular}

\section{Implicitation}

Different from the explicitation, implicitation is a technique where the translator is trying to allow the situation indicates the information which is available in the text. In Table 6, there is "It's hard" which is translated into
"Sulit" and "But he'll tell Tarkie!" which is translated into "Tapi nanti dia memberitahu Tarkie!". In the first example, only "hard" is translated and in the second example, "he'll..." the "will ('1l')" is not found in the TT. 
Table 6. Examples of implicitation

\begin{tabular}{l|ll}
\multicolumn{1}{c|}{ Source Text } & \multicolumn{1}{c}{ Target Text } \\
\hline 'This is big stuff. It's hard.' & 'Ini masalah besar. Sulit.' \\
\hline 'But he'll tell Tarkie!' Tears start pouring down & 'Tapi nanti dia memberitahu Tarkie!' Air mata \\
Suze's face. & mulai meleleh di wajah Suze. \\
\hline
\end{tabular}

\section{Addition}

Addition is a technique included in amplification. Addition itself has function to add more information in order to help delivering the message as well as the meaning to the target reader. In Table 7 , in the first example, "I'd noticed" is translated into "Kuperhatikan begitu" which means there is an addition, "begitu" in the TT. Moreover, in the second example, there is "kan" which is not found in the ST. These additions will help the readers gain better understanding and meaning from what they read.

Table 7. Examples of addition

\begin{tabular}{l|l}
\hline \multicolumn{1}{c|}{ Source Text } & \multicolumn{1}{c}{ Target Text } \\
\hline $\begin{array}{l}\text { 'Who, Suze?' Luke gives a little wince. 'I'd } \\
\text { noticed.' }\end{array}$ & $\begin{array}{l}\text { 'Siapa, Suze?' Luke meringis kecil. 'Kuperhatikan } \\
\text { begitu.' }\end{array}$ \\
\hline $\begin{array}{l}\text { 'You realize that Alicia's trying to psych you } \\
\text { out?' says Luke, and he sounds so sure that I lift } \\
\text { my head in astonishment. }\end{array}$ & $\begin{array}{l}\text { kata Ladar, kan, Alicia berusaha mengintimidasimu,' dan dia terdengar begitu yakin sampai } \\
\text { kuangkat kepalaku saking takjubnya. }\end{array}$ \\
\hline
\end{tabular}

\section{Transposition}

This technique changes the grammatical part on the source text (ST), such as noun in the source text becomes verb in the target text

and vice versa. As it can be seen in the example below, the word "drink" changes from noun becomes "minum" in TT as verb.

Table 8. Example of transposition

\begin{tabular}{l|l}
\hline \multicolumn{1}{c}{ Source Text } & \multicolumn{1}{c}{ Target Text } \\
\hline $\begin{array}{l}\text { 'Let's get a drink.' I check my phone and see a } \\
\text { new text. Luke's on his way. }\end{array}$ & $\begin{array}{l}\text { 'Ayo kita minum.' Kuperiksa ponselku dan melihat } \\
\text { pesan baru. Luke sedang menuju ke sini. }\end{array}$ \\
\hline
\end{tabular}

\section{Reduction}

Reduction is different from implicitation because reduction itself means make it simple, decrease the word(s), or condense the words, but it does not decrease the information from the source text. As it can be seen in the example below, 'Yes, I can', is translated as 'Tentu bisa', which is the 'Yes' and 'I' are removed. Although the translator deleted several words in the target text, that is acceptable because the translation itself is common in the target reader.

Table 9. Example of reduction

\begin{tabular}{l|l}
\hline \multicolumn{1}{c|}{ Source Text } & \multicolumn{1}{c}{ Target Text } \\
\hline 'Yes, I can. That was my strategy.' & 'Tentu bisa. Itu strategiku \\
\hline 'Yes and one day she'll focus properly and see & 'Ya, dan pada suatu hari nanti matanya akan fokus \\
exactly who and what Alicia is,' says Luke dryly & $\begin{array}{l}\text { dan melihat siapa dan seperti apa persisnya Alicia } \\
\text { as he jabs the elevator button. }\end{array}$ \\
\hline
\end{tabular}

\section{Linguistic compression}

Linguistic compression is a technique focused on condensing the linguistic elements in the target text. Although this technique is usually used in interpreting or sub-titling, but sometimes translator uses it in translating a text. As it can be seen in the example below, 'No, he's not!' is synthesized to be 'Tidak' and it is understandable and also accepted in the target text reader. 
Table 10. Examples of linguistic compression

\begin{tabular}{l|l}
\hline \multicolumn{1}{c|}{ Source Text } & \multicolumn{1}{c}{ Target Text } \\
\hline 'No, he's not!' & 'Tidak' \\
\hline 'Maybe you are.' She glowers back at me. & 'Mungkin begitu.' Dia balas memelototiku. \\
\hline
\end{tabular}

\section{Literal}

Literal is a technique used to translate the source text by translating it word by word.
As it can be seen in the example below, 'research' in the source text is translated into 'risetku', and 'for' is translated into 'untuk.'

Table 11. Examples of literal

\begin{tabular}{l|l}
\hline \multicolumn{1}{c|}{ Source Text } & \multicolumn{1}{c}{ Target Text } \\
\hline 'I'm doing my own research.' & 'Aku sedang melakukan risetku sendiri.' \\
\hline $\begin{array}{l}\text { 'We're here for a reason, Raymond, so you'd } \\
\text { better give us what we need.' }\end{array}$ & $\begin{array}{l}\text { 'Kami datang untuk suatu alasan, Raymond, jadi } \\
\text { lebih baik kau member yang kami butuhkan.' }\end{array}$ \\
\hline
\end{tabular}

\section{Generalization}

Translator uses generalization to translate 'Guy' in the source text which is translated into 'Pria' in the target text. Generalization is used if the translator is trying to express the word(s) without losing the meaning of it, but in more general term(s).

Table 12. Example of generalization

\begin{tabular}{c|c}
\hline Source Text & Target Text \\
\hline 'Guy up at Red Ranch?' & 'Pria yang tinggal di Red Ranch?' \\
\hline
\end{tabular}

\section{Discursive creation}

Discursive creation can be called as a technique for translating the target text, but it is out of context. Sometimes, it is used by the translator in order to catch the reader's attention. As it can be seen in the example below, the target text of 'Melakukan apa?' has different meaning with the source text, 'For what?'. It is definitely out of context.

Table 13. Example of discursive creation

\begin{tabular}{c|l}
\hline \multicolumn{1}{c|}{ Source Text } & \multicolumn{1}{c}{ Target Text } \\
\hline 'For what?' & 'Melakukan apa?' \\
\hline
\end{tabular}

\section{Linguistic amplification}

Linguistic amplification is the opposite of linguistic compression in which in the linguistic amplification, the translator adds linguistic element(s) which is not available in the source text, but appears in the target text. As it can be seen in the example below, 'you are' is translated into 'kau temanku.'

Table 14. Example of linguistic amplification

\begin{tabular}{c|l}
\hline \multicolumn{1}{c}{ Source Text } & \multicolumn{1}{c}{ Target Text } \\
\hline 'You are' & 'Kau temanku' \\
\hline
\end{tabular}

\section{Translation acceptability}

Acceptability is the second aspect from the three aspects of translation quality assessment proposed by Nababan, Nuraeni, and Sumardiono (2012). In assessing the acceptability aspect, there are three range of scores, 3 for acceptable, 2 is less acceptable, and 1 for not acceptable. Based on the FGD results, from 134 data and 14 translation techniques found during the research, 124 data are acceptable, 10 less acceptable, and none of them is not acceptable. Techniques used by the translator bring such huge impact in the assessment. 
Table 15. Example of acceptable translation

\begin{tabular}{c|c}
\hline Source Text & Target Text \\
\hline 'She's using it as a dolly plate.' & 'Dia menggunakannya sebagai piring boneka.' \\
\hline
\end{tabular}

The example above shows that the translator is able to transfer the meaning without any grammatical errors and accepted by the target reader because it feels natural, prevalent, familiar, and fulfills the norm, rules, and culture in the target reader. There are some techniques used by the translator to produce the highest score of acceptability, such as established equivalent, modulation, variation, addition, implicitation, transposition, explicitation, generalization, linguistic compression, linguistic amplification, discursive creation, and reduction.

Table 16. Example of less acceptable

\begin{tabular}{c|c}
\hline \multicolumn{1}{c|}{ Source Text } & Target Text \\
\hline 'She's using it as a dolly plate.' & 'Dia menggunakannya sebagai piring boneka.' \\
\hline
\end{tabular}

Meanwhile, some techniques make the translation results get less acceptable, such as pure borrowing and literal because the translator still uses the foreign term in translating the words, phrases, clauses, or sentences. Although the translation generally feels natural, but some of the words or terms used in the target text do not suit with the norm or culture in the target reader.

\section{CONCLUSION}

Based on the analysis, it can be concluded that there are fourteen (14) techniques found in the translation of Shopaholic to the Rescue novel, such as established equivalent, variation, modulation, pure borrowing, literal, discursive creation, addition, explicitation, implicitation, transposition, reduction, generalization, linguistic amplification, and linguistic compression. Moreover, the most used technique is established equivalent since this technique uses terms or words based on the dictionary and prevalent with the target reader. Furthermore, based on the data, the score of acceptability of the translations is 2.94 which is categorized as acceptable. This score is considered high because the highest score of acceptability is 3 . Based on the results, the translations of the complaining responding turn in the novel of 'Shopaholic to the Rescue' are claimed as acceptable and follow the norms as well as the rule of the target language.

\section{ACKNOWLEDGEMENT}

This study is supported, helped, and assisted by the research advisors, Mr. Mangatur Nababan and Mr. Djatmika in order to achieve Master degree in Linguistics program at Sebelas Maret University.

\section{REFERENCES}

Abdurrahman, H., \& Soedjono. (1999). Metode penelitian deskriptif. Jakarta: Rineka Cipta.

Larsson, M. L. (1998). Meaning based translation: A guide to cross language equivalence. Lanham \& New York: University Press of America.

Mahesti, A. D. (2016). Analisis terjemahan tuturan yang merepresentasikan tindak tutur mengeluh dalam novel Little Women. Surakarta: Universitas Sebelas Maret.

Mey, J. L. (2001). Pragmatics: An introduction. Oxford: Blackwell.

Molina, L., \& Albir, H. A. (2002). Translation techniques revisited: A dynamic and functionalist approach. Meta: Translators' Journal, 47(4), 498. Retrieved from: http://doi.org/10/7202/008033ar.

Nababan, M. R. (1997). Aspek teori penerjemahan dan pengalihbahasaan. Surakarta: Universitas Sebelas Maret.

Nababan, M. R. (2003). Teori menerjemah bahasa Inggris. Yogyakarta: Pustaka Pelajar.

Nababan, M. R. (2007). Aspek genetik, objektif dan afektif dalam penelitian penerjemahan. Linguistika, 14(26), 15-23.

Nababan, M. R., Nuraerni, A., \& Sumardiono. (2012). Pengembangan model penilaian kualitas terjemahan. Kajian Linguistik dan Sastra, 24(1), 39-57.

Nuraeni, A. (2008). Perbandingan terjemahan tindak tutur mengeluh dalam film Bad Boys II yang ditayangkan di stasiun televisi dan VCD (Kajian strategi penerjemahan, kesepadanan makna dan 
Setia Adi Nugraha, Mangatur Nababan, \& Djatmika

The translation acceptability of complain responding turn in shopaholic to the rescue

keberterimaan). Surakarta: Universitas Sebelas Maret.

Nurhasanah, G. (2010). Tindak tutur mengeluh dalam bahasa Jepang. Depok: Universitas Indonesia.

Santosa, R. (2014). Metode penelitian kualitatif. Surakarta: Universitas Sebelas Maret.
Sutopo, H. B. (2002) Metode penelitian kualitatif: Dasar teori dan terapannya dalam penelitian (Qualitative research methodology: Basic theories and their application to research). Surakarta: Sebelas Maret University Press.

Yule, G. (1996). Pragmatics. Cambridge: Cambridge University Press. 